Vol.3 No.1 Hal. $70-75$

Juni 2020

\title{
Pemanfaatan Ekstrak Kulit Nanas (Ananas comosus L.) Dalam Pembuatan Hand Wash Sebagai Antibakteri
}

\author{
${ }^{(1)}$ Adilah Wirdhani Lubis, ${ }^{(2)}$ Julia Maulina \\ Universitas Islam Sumatera Utara, Pendidikan Kimia ${ }^{(1)(2)}$ \\ Wirdhani dila@ @kip.uisu.ac.id ${ }^{(1)}$, $\underline{\text { Julia.maulina @ fkip.uisu.ac.id }}{ }^{(2)}$
}

\begin{abstract}
ABSTRAK
Pada umumnya limbah kulit nanas di buang dan menjadi sampah yang tidak tertangani, padahal dari hasil uji fitokimia kulit nanas mengandung senyawa flavonoid, tanin dan saponin serta mengandung senyawa yang berpotensi sebagai antibakteri. Salah satu pemanfaatan limbah kulit nanas (Ananas comosus L.) yaitu dengan menambahkan kulit nanas yang diolah menjadi ekstrak yang kemudian ditambahkan pada proses pembuatan Hand Wash atau sabun cair cuci tangan. Tujuan penelitian ini adalah untuk mengetahui pengaruh ekstrak kulit nanas (Ananas comosus L.) sebagai anti bakteri pada pembuatan Hand Wash. Selanjutnya dilakukan pengujian aktivitas antibakteri pada Eschericia coli dan Staphylococcus aureus. Hasil uji menunjukkan bahwa ekstrak kulit nanas yang diaplikasikan sebagai Hand Wash dapat menghambat pertumbuhan bakteri dengan baik yang menghasilkan zona hambat sebesar $9,9 \mathrm{~mm}$ pada Eschericia coli dan 10,9 mm pada Staphylococcus aureus.
\end{abstract}

Kata Kunci : Ekstrak kulit nanas, aktivitas bakteri

\begin{abstract}
In general, pineapple skin waste is discarded and becomes untreated waste, whereas the results of the phytochemical test of pineapple skin contain flavonoids, tannins and saponins and contain compounds that have potential as antibacterial properties. One of the utilization of pineapple skin waste (Ananas comosus L.) is by adding pineapple skin which is processed into an extract which is then added to the process of making Hand Wash or hand washing liquid soap. The purpose of this study was to determine the effect of pineapple skin extract (Ananas comosus L.) as an anti-bacterial in the manufacture of Hand Wash. Then the antibacterial activity was tested on Eschericia coli and Staphylococcus aureus. The test results showed that pineapple peel extract which was applied as Hand Wash could inhibit bacterial growth well which resulted in inhibition zones of $9.9 \mathrm{~mm}$ in Eschericia coli and $10.9 \mathrm{~mm}$ in Staphylococcus aureus.
\end{abstract}

Keywords : Pinneaple skin extract, antibacterial activity 


\section{PENDAHULUAN}

\section{Latar Belakang}

Kebersihan merupakan hal yang sangat penting untuk dijadikan gaya hidup. Dengan menjaga kebersihan maka kesehatan tubuh juga akan ikut terjaga, apalagi kebersihan tangan penting untuk selalu dijaga mengingat segala aktivitas kegiatan masyarakat pastilah menggunakan tangan. Namun, kesadaran masyarakat dalam menjaga kebersihan tangan masih kurang sehingga terkontaminasi oleh bakteri yang akibatnya menganggu kesehatan tubuh yang disebabkan oleh bakteri tersebut seperti infeksi dan diare. Diare dan infeksi merupakan penyakit yang sering terjadi ketika tidak menjaga kebersihan tangan. Salah satu bakteri penyebab penyakit diare yaitu Escherichia coli dan Staphylococcus aureus yang merupakan bakteri usus. Infeksi dapat menyerang tumbuhan, hewan dan manusia yang dapat ditularkan secara langsung dari satu orang ke oramg lain, misalnya melalui batuk, bersoin, dan berciuman (Price dan Wilson, 2005). Bakteri Staphylococcus aureus merupakan salah satu bakteri yang melekat di tangan manusia. Staphylococcus aureus menyebabkan berbagai infeksi pada manusia seperti pneumonia, meningitis, infeksi saluran kemih dan keracunan makanan dengan cara melepaskan enterotoxin ke dalam makanan (Thaker et al., 2009). Oleh karena itu, perlu dilakukan pencegahan agar mengurangi terjadinya diare maupun infeksi. Cara paling efektif untuk mencegah diare adalah dengan menjaga kebersihan tangan terutama saat sebelum makan dan minum dengan menggunakan sabun cuci tangan cair yang mengandung antibakteri. Sabun adalah suatu sediaan yang dipergunakan oleh masyarakat sebagai pencuci pakaian dan pembersih kulit. Berbagai jenis sabun yang beredar di pasaran dalam bentuk yang bervariasi,mulai dari sabun cuci, sabun cuci tangan,sabun pembersih peralatan rumah tangga dalam bentuk krim,padatan dan batangan, bubuk dan bentuk cair (Ari dan Budiyono, 2004). Sabun cair saat ini banyak diproduksi karena penggunaannya yang lebih praktis dan bentuknya yang menarik disbanding bentuk sabun lain saat ini. Disamping itu sabun dapat digunakan untuk mengobati dan membunuh bakteri dan jamur. (Depkes, 2007) tentang cuci tangan, masyarakat di anjurkan untuk mencuci tangan dengan sabun cuci tangan. Karena dengan mencuci tangan dapat membersihkan tangan dan kukudari infeksi penyakit,debu dan kotoran. Perbedaan mencuci tangan dengan sabun cuci tangandan denganair saja tanpa sabun cuci tangan adalah pemakain sabun cuci tangan lebih efisien untuk menghilangkan kuman tidak kasat mata yang menempel ditangan di bandingkan dengan mencuci tangana dengan air saja tanpa sabun.

\section{Perumusan Masalah}

Salah satu keanekaragaman hayati yang memiliki potensi untuk dikembangkan sebagai antibakteri adalah limbah kulit nanas (Ananas comosus) yang mengandung senayawa kimia yang bersifat antibakteri. Pada buah nanas memiliki senyawa flavonoid yang bersifat desinfektan dan sangat efektif dalam menghambat pertumbuhan bakteri Gram positif karena flavonoid bersifat polar sehingga lebih mudah menembus lapisan peptidoglikan yang juga bersifat polar pada bakteri Gram positif daripada lapisan lipid yang non polar. Pada dinding sel bakteri Gram positif mengandung polisakarida (asam trikoat) yang merupakan polimer larut dalam air, yang berfungsi sebagai transfer ion positif untuk keluar masuk. Sifat larut itulah yang menunjukkan bahwa dinding sel Gram positif bersifat lebih polar. Setelah masuk flavonoid segera bekerja menghancurkan bakteri dengan cara mendenaturasi protein yang dapat menyebabkan aktifitas metabolism. Sel bakteri berhenti karena semua aktifitas metabolisme sel bakteri dikatalis oleh suatu enzim yang merupakan protein. Berhentinya aktifitas metabolism ini akan mengakibatkan kematian sel bakteri. (Suerni et al., 2013). 


\section{Tujuan Penelitian}

Beberapa penelitian yang telah dilakukan mengenai uji daya antibakteri dari ekstrak buah nanan antara lain Suerni et al. (2013) melakukan uji daya hambat ekstrak buah nanas, salak dan manga kweni terhadap bakteri Staphylococcus aureus yang menunjukkan hasil dimana ekstrak buah nanas dapat menghambat pertumbuhan bakteri Staphylococcus aureus dengan konsentrasi $50 \%$ dan $100 \%$. Chandra et al. (2010) juga melakukan penelitian tentang aktivitas antibakteri ekstrak kulit nanas dengan pelarut kloroform, aseton dan methanol, yang hasilnya menujukkan ekstrak kloroform kulit nanas memiliki aktivitas terhadap Staphylococcus aureus, Corynebacterium rubrum, Klebsiella peneumonia dan $S$. typhimurium, tetapi tidak menunjukkan adanya aktivitas terhadap bakteri $S$. subflava, Enterobacter aerogenes dan Proteus mirabilis. Ekstrak aseton kulit nanas menujukkan aktivitas terhadap Staphylococcus aureus, S. subfalva, Enterobacter aerogenes, Klebsiella pneumonia, Proteus mirabilis dan S. typhimurium. Ektrak methanol menunjukkan aktivitas terhadap Staphylococcus aureus dan Klebsiella pneumonia, tetapi tidak menunjukkan aktivitas terhadap S. subflava, Eterobacter aerogenes, Proteus mirabilis, dan $S$. typhimurium. Berdasarkan kandungan kimia dan pemanfaatan dari kulit nanas (Ananas comosu L.) dilakukan pembuatan sabun cair dengan penmabahan ekstrak kulit nenas(Ananas coomosus.L) terhadap pengaruhnya sebagai aktivitas antibakteri

\section{METODE PENELITIAN \\ Waktu dan Lokasi Penelitian}

Pelaksanaan penelitian berlokasi di laboratorium MIPA Kimia FKIP Universitas Islam Sumatera Utara (UISU), laboratorium Teknologi Bioproses Perguruan Teknologi Kimia Industri Medan (PTKI) dan Laboratorium Dinas Perindustrian Kota Medan dan jangka waktu pelaksanaan penelitian selama 3 bulan.

\section{Alat dan Bahan Penelitian}

Alat yang digunakan dalam penelitian ini adalah penghalus (blender), pisau, gelas ukur, erlenmeyer, cawan penguap, kaca arloji, batang pengaduk, corong saring, buret, pipet tetes, $p \mathrm{H}$ meter, stormer, sentrifuse timbangan, pengaduk, ember, saringan dan botol kemasan. Bahan yang digunakan dalama penelitian ini adalah ekstrak kulit nanas, buffer fosfat, texapon, $\mathrm{NaCl}$, trollion, foam boster, pewarna, parfum, dewisilliquid dan $\mathrm{NaOH}$.

\section{Prosedur Penelitian}

\section{Tahap I. Pembuatan Ekstrak Kulit Nanas}

Pada tahap awal penelitian ini dilakukan pembuatan ekstrak kulit nanas. Kulit nanas dalam penelitian ini diperoleh dari limbah penjual rujak di simpang jodoh pasar 7 tembung Medan yang kemudian dijadikan ekstrak kulit nanas. Pembuatan ekstrak kulit nanas yaitu kulit nanas yang telah dibersihkan dipotong kecil-kecil tambahkan buffer fosfat $0,1 \mathrm{M} \mathrm{pH} 7$ dihaluskan dengan menggunakan blender, hasil blender diperas, hasil perasan disimpan disuhu ruangan selama 24 jam supaya mengendap. Ambil hasil endapan kemudian disentrifuse dengan kecepatan $3500 \mathrm{rpm}$ selama 15 menit diperoleh filtrat yang mengandung ekstrak kulit nanas (Darwis \& Sakara, 1990).

\section{Tahap II. Pembuatan Sabun Cair dengan Penambahan Ekstrak Kulit Nanas}

Pada tahap II dilakukan pembuatan sabun cair dengan penambahan ekstrak kulit nanas. Diawali dengan pencampuran semua bahan baku sabun cair yang diaduk dengan pengaduk kayu sampai tercampur rata. Kemudian dilakukan penambahan ekstrak kulit nanas dan diaduk lagi sampai tercampur rata dan homogen. Selanjutnya sabun cair dievaluasi untuk melihat aktivitas antibakteri 


\section{Tahap III. Pengujian Aktivitas Antibakteri}

Pada tahap III sampel yang merupakan sabun cair dengan penambahan ekstrak kulit nanas dilakukan evaluasi untuk melihat aktivitas antibakteri terhadap bakteri Escherichia coli dan Staphylococcus aureus.

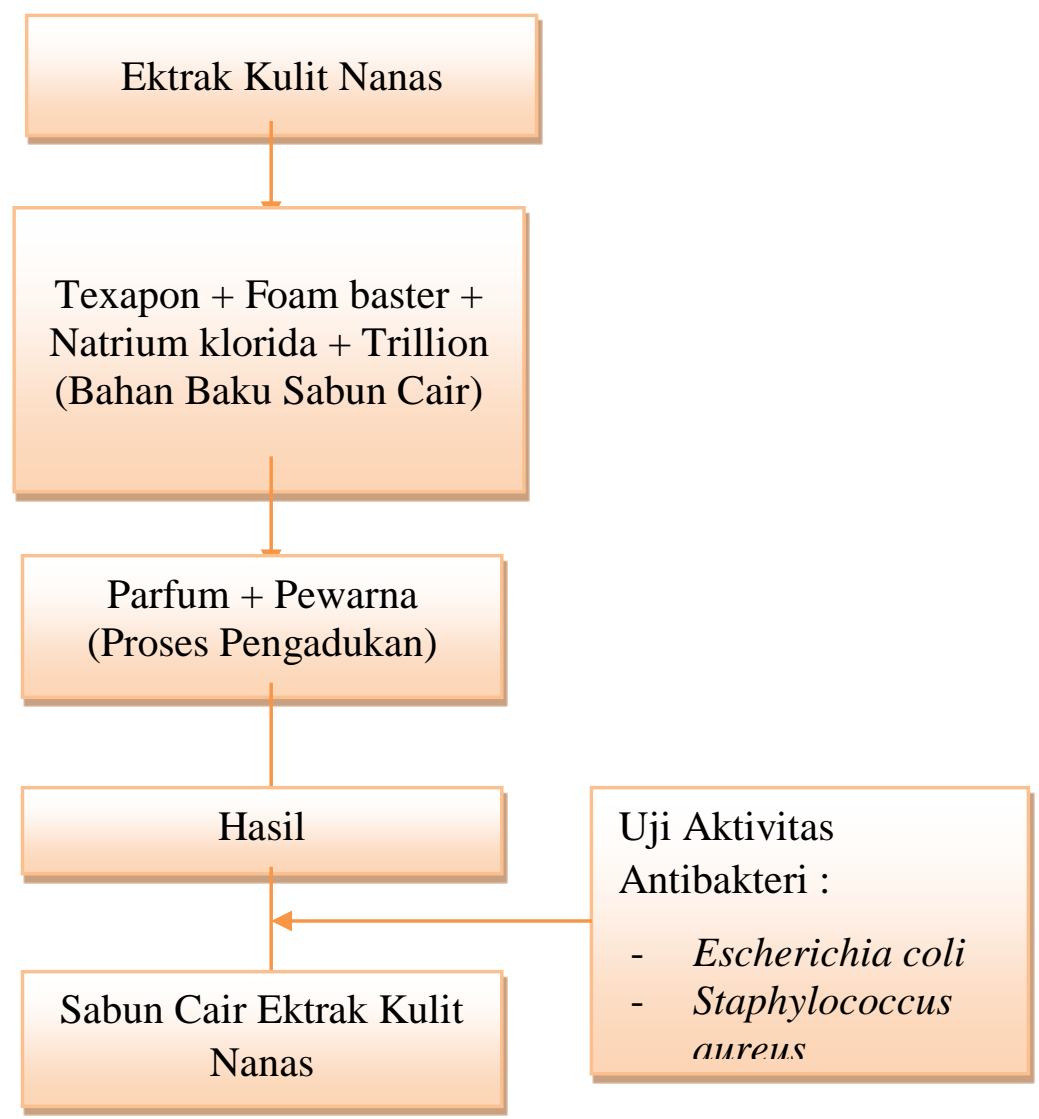

Gambar. Diagram alir pembuatan sabun cuci tangan dengan penambahan ektrak kulit nanas

\section{Jenis Penelitian}

Jenis Penelitian ini adalah penelitian eksperimental. Penelitian ini 3 kali perlakuan dimana untuk mendapatkan hasil yang akurat.

\section{Teknik Pengumpulan Data}

Pengumpulan data dilakukan dengan menggunakan analisis deskriptif kuantitatif. Pada penelitian ini peneliti memperoleh data uji aktivitas antibakteri dengan melakukan percobaan secara langsung yang dilakukan dilaboratorium.

\section{Teknik Analisis Data}

Analisis data penelitian ini melalui pendekatan analitik kuantitatif deskriptif yaitu menjelaskan aktivitas anti bakteri dalam bentuk uraian yang didukung oleh teori-teori yang ada. Hasil penelitian berupa data 


\section{HASIL DAN PEMBAHASAN}

Hasil Pengujian Aktivitas Antibakteri

Pengujian Aktivitas Antibakteri Terhadap Eschericia coli

\begin{tabular}{|l|l|l|l|l|l|}
\hline No. & Nama Bakteri & Konsentrasi & $\begin{array}{l}\text { Diameter } \\
\text { Cakram } \\
(\mathbf{m m})\end{array}$ & $\begin{array}{l}\text { Diameter } \\
\text { Zona } \\
\text { Hambat } \\
(\mathbf{m m})\end{array}$ & $\begin{array}{l}\text { Indeks } \\
\text { Anti } \\
\text { mikrobial }\end{array}$ \\
\hline 1 & \multirow{2}{*}{ Eschericia coli } & Pure & \multirow{2}{*}{6} & 9,6 & 0,6 \\
\cline { 1 - 3 } & & & 9,9 & 0,65 \\
\cline { 1 - 1 } & & & 10,2 & 0,7 \\
\hline
\end{tabular}

\section{Perhitungan :}

$$
\begin{aligned}
\text { Indeks A. Mikrobial } & =\frac{\text { Diameter } \text { zona hambat }- \text { diameter cakram }}{\text { diameter cakram }} \\
& =\frac{(9,6-6) \mathrm{mm}}{6 \mathrm{~mm}} \\
& =0,6
\end{aligned}
$$

\begin{tabular}{|c|c|c|c|c|c|}
\hline No. & Nama Bakteri & Konsentrasi & $\begin{array}{l}\text { Diameter } \\
\text { Cakram } \\
(\mathrm{mm})\end{array}$ & $\begin{array}{l}\text { Diameter } \\
\text { Zona } \\
\text { Hambat } \\
(\mathbf{m m})\end{array}$ & $\begin{array}{l}\text { Indeks } \\
\text { Anti } \\
\text { mikrobial }\end{array}$ \\
\hline 1 & \multirow{3}{*}{$\begin{array}{l}\text { Staphylococcus } \\
\text { aureus }\end{array}$} & \multirow{3}{*}{ Pure } & \multirow{3}{*}{6} & 10,6 & 0,76 \\
\hline 2 & & & & 10,9 & 0,81 \\
\hline 3 & & & & 11,2 & 0,86 \\
\hline
\end{tabular}

\section{Pengujian Aktivitas Antibakteri Terhadap Staphylococcus aureus}

\section{Perhitungan :}

Indeks A. Mikrobial $=\frac{\text { Diameter } \text { zona hambat }- \text { diameter } \text { cakram }}{\text { diameter } \text { cakram }}$

$$
\begin{aligned}
& =\frac{(10,6-6) \mathrm{mm}}{6 \mathrm{~mm}} \\
& =0,76
\end{aligned}
$$

\section{PEMBAHASAN}

Berdasarkan hasil pengujian aktivitas antibakteri ekstrak kulit nanas dalam sediaan Hand wash terhadap bakteri Eschericia coli dan Staphylococcus aureus menunjukkan bahwa ekstrak kulit nanas dalam sediaan Hand wash efektif menghambat bakteri dan seiring dengan bertambahnya konsentrasi ekstrak kulit nanas, zona hambat yang dihasilkan juga semakin besar. Senyawa aktif dalam kulit buah nanas sudah banyak diteliti aktivitas antibakterinya terhadap beberapa bakteri, baik bakteri Gram positif maupun Gram negatif. Seperti pada penelitian Suerni et al. (2013) yang meneliti daya antibakteri dari beberapa buah salah satunya buah nanas yang memberikan daya hambat bakteri terhadap Staphylococcus aureus. Rahman (2012) telah meneliti daya hambat hand sanitizer dengan bahan aktif kitosan terhadapbakteri Escherichia coli dan Staphylococcus aureus. Hasil menunjukkan dengan 
Lubis AW, Maulina J : Pemanfaatan Ekstrak Kulit Nanas (Ananas comosus L.) Dalam Pembuatan Hand Wash Sebagai Antibakteri

konsentrasi kitosan 0,50\% aktivitas antibakteri Escherichia coli adalah $11 \mathrm{~mm}$, sedangkan dengan konsentrasi kitosan 0,75\% aktivitas antibakteri Staphylococcus aureus adalah $13 \mathrm{~mm}$

\section{KESIMPULAN}

Berdasarkan hasil penelitian dapat disimpulkan bahwa ekstrak kulit nanas dalam sediaan Hand wash dapat menghambat pertumbuhan bakteri dan semakin ditambahkan ekstrak kulit nanas maka semakin besar aktivitas daya hambat terhadap bakteri Escherichia coli dan bakteri Staphylococcus aureus.

\section{DAFTAR PUSTAKA}

Ari, Wibisana. dan Budiyono. 2004. Pembuatan Sabun Cair Dengan Bahan Dasar Alkil Benzen Sulfonat. (http://www.angelfire.com, accessed on Februari 2007).

Chanda, S., Baravalia, Y., Kaneria, M. and Rakholia, K. 2010. Current Research Technology and Education Topic in Applied Microbiology and Microbial Biotechnology. A. Mendez-Vilas (Ed). Pp $444-450$.

Darwis, A. Azis. Dan Sakara, E. 1990. Isolasi, Pemurnian dan Karakterisi Enzim. Bogor: IPB

Depkes, RI.(2007). Pendidikan kesehatan. www.depkes.go.id.

Price, S. dan Wilson, L. 2005. Patofisiologi: Konsep Klinis Proses-Proses Penyakit. Edisi

6. EGC, Jakarta.

Rahman, M.A. 2012. Kitosan sebagai bahan antibakteri alternatif dalam formulasi gel pembersih tangan (Hand Sanitizer). Bogor. Institut Pertanian Bogor. Skripsi.

Suerni Endang, Alwi Muhammad dan Guli Musjaya M. 2013. Uji Daya Hambat Ekstrak Buah Nanas (Ananas comosus L. Merr.), Salak (Salacca edulis Reinw.) dan Mangga Kweni (Mangifera odorata Griff.) terhadap Daya Hambat Staphylococcus Aureus. Universitas Tadulako Kampus Bumi Tadulako Tondo Palu. Sulawesi Tengah.

Thaker S., Lodhia M.H., Bhatt K.R 2009. Antibacterial Activity of Essential Oils from Palmarosa, Evening Primrose, Lavender and Tuberose. India. Journal of Pharmaceutical Sciences, 134-136. 